\title{
Sosialisasi Cuci Tangan Pakai Sabun Dengan Air Mengalir Sebagai Upaya Pencegahan Covid-19 Pada Siswa-Siswi SD Muhammadiyah Sintang, Kalimantan Barat
}

\author{
Abil Rudi \\ Program Studi Perekam dan Informasi Kesehatan, STIKes Kapuas Raya Sintang, Indonesia, 78612 \\ E-mail : abilrudistg@gmail.com \\ DOI : https://doi.org/10.37339/jurpikat.v1i3.337
}

Info Artikel:

Diterima:

18-10-2020

Diperbaiki:

10-12-2020

Disetujui:

21-12-2020

Kata Kunci: Cuci tangan pakai sabun, 6 langkah muncuci tangan, Siswa SD, COVID-19

Keywords: Wash hands with soap, 6 steps to wash hands, Elementary school students, COVID-19
Abstrak : Pengabdian ini bertujuan untuk mencegah penularan COVID-19 kepada siswa-siswi SD Muhammadiyah Sintang, melalui cuci tangan pakai sabun dengan air yang mengalir. Metode pelaksanaan kegiatan ini dengan 6 langkah mencuci tangan. Langkah pertama basahi tangan, gosok sabun pada telapak tangan kemudian usap dan gosok kedua telapak tangan secara lembut dengan arah memutar. Langkah kedua usap dan gosok kedua punggung tangan secara bergantian. Langkah ketiga gosok sela-sela jari tangan hingga bersih. Langkah keempat bersihkan ujung jari secara bergantian dengan posisi saling mengunci. Langkah kelima gosok dan putar kedua ibu jari secara bergantian. Langkah keenam letakkan ujung jari ke telapak tangan kemudian gosok perlahan dan bilas dengan air bersih serta keringkan. Dari kegiatan ini diharapkan cuci tangan pakai sabun dengan air yang mengalir dapat mematikan virus dan memutuskan mata rantai penularan COVID-19 serta meningkatkan kesehatan dan kewaspadaan siswa-siswi terhadap COVID-19.

Abstract: This service aims to prevent the transmission of COVID-19 to students of SD Muhammadiyah Sintang, by washing hands with soap with running water. The method of implementing this activity is with 6 hand measurement steps. The first step is wet your hands, rub the soap on your palms then use and rub your hands gently in a circular direction. The second step is rubbing and rubbing both hands back alternately. Step three rub between your fingers until they are clean. The fourth step is to clean the fingertips alternately with the proper rank. Step five rub and rotate the thumbs alternately. The sixth step put your fingertips on your palms then rub gently and rinse with clean water and dry. From this activity, it is hoped that washing soap hands with running water can kill the virus and break the chain of transmission of COVID-19 and improve the health and awareness of students against COVID-19. 


\section{Pendahuluan}

COVID-19 suatu penyakit menular yang disebabkan oleh jenis coronavirus yang baru ditemukan. Virus baru dan penyakit yang disebabkannya ini tidak dikenal sebelum mulainya wabah di Wuhan, Tiongkok, bulan Desember 2019. COVID-19 ini sekarang menjadi sebuah pandemi yang terjadi di banyak negara di seluruh dunia. Pada bulan maret 2020 COVID-19 telah menewaskan lebih dari 7 ribu orang dan menginfeksi 180 ribu orang di seluruh dunia. Jumlah negara yang terjangkit adalah 162 negara, yang menyebabkan Coronavirus ditetapkan sebagai pandemi. Dimulai dari wilayah China, mulai muncul kasus serupa di Korea Selatan, Iran, Itali, Jepang, Australia bahkan Amerika Serikat (WHO, 2020). COVID-19 ditetapkan sebagai pandemi dan menjadi Emergency of International Concern (PHEIC) kesehatan masyarakat pada 11 Maret 2020. Indonesia pertama kali melaporkan 2 kasus positif pada 2 Maret 2020 dan kasus positif terus meningkat (Susilawati, 2020).

COVID-19 dapat menyebabkan gejala ringan termasuk pilek, sakit tenggorokan, batuk, dan demam. Sekitar $80 \%$ kasus dapat pulih tanpa perlu perawatan khusus. Sekitar 1 dari setiap 6 orang mungkin akan menderita sakit yang parah, seperti disertai pneumonia atau kesulitan bernafas, yang biasanya muncul secara bertahap. Walaupun angka kematian penyakit ini masih rendah yakni sekitar 3\%, namun bagi orang yang berusia lanjut, dan orang-orang dengan kondisi medis yang sudah ada sebelumnya seperti diabetes, tekanan darah tinggi dan penyakit jantung, mereka biasanya lebih rentan untuk menjadi sakit parah. Melihat perkembangan hingga saat ini, lebih dari 50\% kasus konfirmasi telah dinyatakan membaik, dan angka kesembuhan akan terus meningkat (Kemenkes RI, 2020).

Angka kejadian COVID-19 di dunia pada 216 negara dengan terkonfirmasi positif sebanyak 17.660 .523 orang dan meninggal dunia sebanyak 680.894 orang. Sedangkan, di Indonesia terkonfirmasi positif COVID-19 sebanyak 353.461 orang, dinyatakan sembuh sebanyak 277.544 orang dan meninngal dunia sebanyak 12.347 orang (SATGAS COVID19).

Penularan COVID-19 terjadi melalui tetesan kecil (droplet) yang dikeluarkan pada saat seseorang batuk atau bersin. Saat ini WHO menilai bahwa risiko penularan dari seseorang yang tidak bergejala COVID-19 sama sekali sangat kecil kemungkinannya. Namun, banyak orang yang teridentifikasi COVID-19 hanya mengalami gejala ringan seperti batuk ringan, atau tidak mengeluh sakit, yang mungkin terjadi pada tahap awal penyakit. Sampai saat ini, para ahli masih terus melakukan penyelidikan untuk menentukan periode penularan atau masa inkubasi COVID-19 (Kemenkes RI, 2020).

Di Negara Indonesia dalam mencegah dan menanggulangi penyebaran virus COVID-19 perlu upaya dari Pemerintah serta peran masyarakat untuk mengatasinya. Berdasarkan himbauan dari Pemerintah RI, sebagai upaya pencegahan serta penanganan 
penularan virus COVID-19, mengharuskan masyarakat menjaga jarak minimal 1 meter, memakai masker dan selalu mencuci tangan dengan sabun. Selain itu, masyarakat harus saling mengingatkan himbauan tersebut antara satu dengan yang lainnya. Bagi Lansia, perlu ekstra penjagaannya karena memiliki imunitas yang kurang baik bila dibandingkan dengan orang berusia muda (Masrul, dkk., 2020). Sedangkan, Badan Kesehatan Dunia (WHO) dan Pusat Pengendalian dan Pencegahan Penyakit Amerika Serika mengeluarkan himbauan mengenai hal yang harus dilakukan dalam mencegah virus corona. Upaya yang bisa dilakukan adalah melakukan berbagai upaya pencegahan, salah satunya adalah Cuci Tangan Pakai Sabut yang disingkat dengan CTPS (Dinkes Pemprov Bali, 2020).

Cuci tangan pakai sabun yang dipraktikkan secara tepat dan benar merupakan cara termudah dan efektif untuk mencegah terjangkitnya penyakit. Mencuci tangan dengan air dan sabun dapat lebih efektif menghilangkan kotoran dan debu secara mekanis dari permukaan kulit dan secara bermakna mengurangi jumlah mikroorganisme penyebab penyakit seperti virus, bakteri dan parasit lainnya pada kedua tangan (Desiyanto dan Djannah, 2013).

Tidak mencuci tangan menggunakan sabun maka dapat menularkan infeksi pada diri sendiri terhadap bakteri dan virus dengan memegang bagian hidung, mata dan mulut. Selain itu juga dapat menyebarkan atau menularkan bakteri kepada orang lain. Penyakit infeksi biasanya terjangkit melalui kontak tangan ke tangan termasuk flu dan common cold (Lestari, 2008). Kemudian, hasil penelitian penelitian yang dilakukan oleh Burton, Cobb, Donachie, Judah, Curtis dan Schmidit (2011) dan Pickering, Boehm, Mwanjali dan Davis (2010), Gracia Risnawaty, menunjukkan bahwa cuci tangan dengan menggunakan sabun lebih efektif dibandingkan dengan cuci tangan hanya dengan menggunakan air.

Program pengabdian ini bertujuan untuk mencegah penularan COVID-19 kepada siswa-siswi SD Muhammadiyah Sintang, melalui cuci tangan pakai sabun dengan air yang mengalir. Terlaksananya kegiatan sosialisasi cuci tangan pakai sabun dengan air mengalir, maka membantu dan menambah wawasan siswa-siswi SD Muhammadiyah Sintang untuk memutuskan mata rantai penularan COVID-19 serta sebagai upaya meningkatkan kesehatan dan kewaspadaan siswa-siswi terhadap COVID-19.

\section{Metode}

Alur pelaksanaan pengabdian pada sosialisasi cuci tangan pakai sabun dengan air mengalir sebagai upaya pencegahan COVID-19 pada siswa-siswi SD Muhammadiyah Sintang, Kalimantan Barat sebagai berikut : 


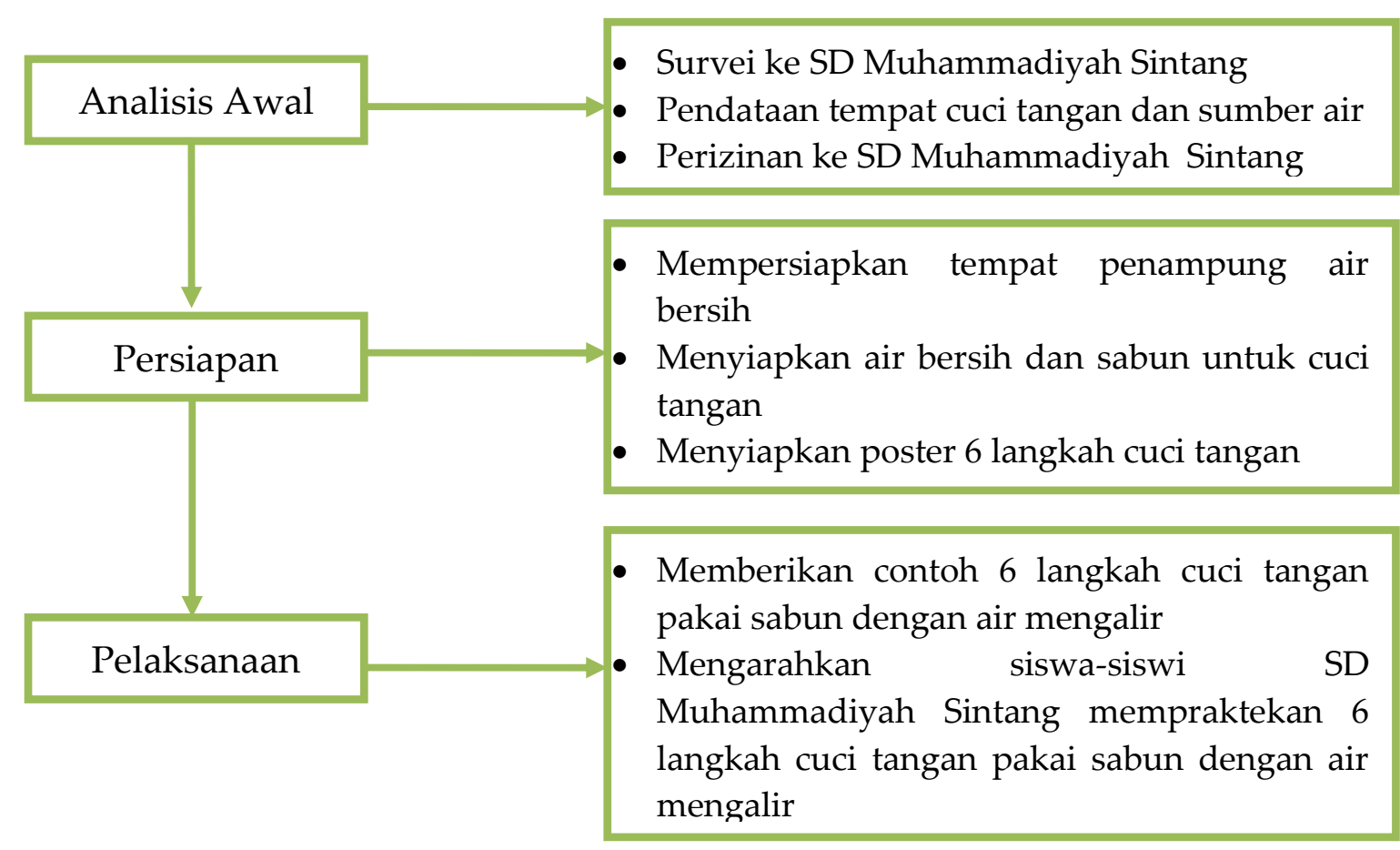

Gambar 1. Alur Pelaksanaan Pengabdian

Metode yang digunakan dalam program pengabdian masyarakat ini, mulai dari penentuan tempat dan sasaran dilakukannya sosialisasi cuci tangan pakai sabun. Survei lapangan ini dilakukan dengan cara berkunjung langsung terlebih dahulu ke tempat pengabdian yang telah ditentukan serta melakukan koordinasi kepada Kepala Sekolah SD Muhammadiyah Sintang, sebagai permohonan izin untuk melakukan kegiatan program pengabdian. Kemudian, melakukan pendataan tempat cuci tangan dan sumber air bersamaan dengan guru piket di SD Muhammadiyah Sintang. Selanjutnya, dilakukan penetapan waktu, hari dan tanggal untuk dilakukannya kegiatan pengabdian masyarakat ini.

Perancangan poster 6 langkah cuci tangan dilakukan dengan mengikuti aturan berdasarkan dari WHO. Menyiapkan tempat penampung air bersih untuk digunakan pada saat praktek cuci tangan bersamaan dengan siswa-siswi SD Muhammadiyah Sintang. Kemudian, pelaksanaan kegiatan dengan memberikan contoh terlebih dahulu 6 langkah cara cuci tangan pakai sabun dengan air mengalir serta mengarahkan siswasiswi SD Muhammadiyah Sintang untuk melakukan praktek 6 langkah cuci tangan pakai sabun dengan air mengalir. Kegiatan ini dilakukan selama 1 hari di SD Muhammadiyah Sintang dan dilakukan pembagian 5 botol sabun cuci tangan, 3 buah tempat penampung air bersih dan 20 buah poster 6 langkah cuci tangan.

Alat dan bahan yang digunakan dalam pengabdian ini meliputi poster 6 langkah cuci tangan sebagai petunjuk untuk melakukan cuci tangan, penampung air yang berfungsi sebagai wadah penampung air untuk melakukan cuci tangan dengan 
air yang mengalir, air dan sabun yang berfungsi untuk membersihkan tangan dari virus sehingga mencegah penularan COVID-19.

\section{Hasil dan Pembahasan}

Pelaksanaan kegiatan pengabdian kepada masyarakat dilakukan di SD Muhammadiyah Sintang, Kalimantan Barat.

Kegiatan pengabdian kepada masyarakat ini dimulai dari permohonan izin kepada Kepala Sekolah SD Muhammadiyah Sintang. Kepala Sekolah SD Muhammadiyah Sintang memberikan izin untuk dilakukannya kegiatan pengabdian kepada masyarakat ini. Program pengabdian kepada masyarakat yang disampaikan kepada Kepala Sekolah beserta guru SD Muhammadiyah Sintang, diapresiasi dan disambut dengan baik.

Kegiatan ini dilaksanakan dalam 1 hari yakni pada tanggal 12 Maret 2020 yang dimulai dari jam 7 pagi sampai jam 12 siang WIB. Bentuk kegiatan pengabdian masyarakat ini berupa sosialisasi cuci tangan pakai sabun dan pembagain 5 botol sabun, 3 tempat penampung air dan 20 buah poster 6 langkah cuci tangan. Program pengabdian kepada masyarakat ini diikuti sebanyak 106 siswa-siswi SD Muhammadiyah Sintang. Proses kegiatan berjalan dengan efektif sesuai jadwal kegiatan dan semua siswa-siswi melakukan praktek cuci tangan pakai sabun dengan air yang mengalir.

Enam langkah cuci tangan merupakan cara yang efektif untuk mencegah penyebaran COVID-19. Penjelasan 6 langkah cuci tangan berdasarkan WHO kepada siswa-siswi SD Muhammadiyah Sintang di dalam ruangan pada gambar 2.

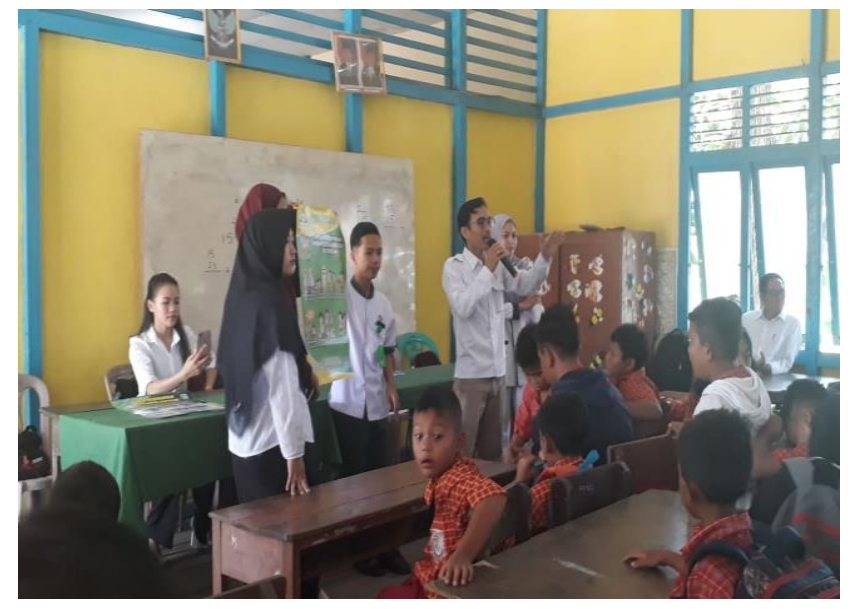

Gambar 2. Penjelasan 6 langkah cuci tangan

Kegiatan diawali dengan mengisi air bersih ke tempat penampung, selanjutnya dilakukan kegiatan praktek 6 langkah cuci tangan. Terlebih dahulu memberikan contoh 6 langkah cara cuci tangan yang benar dan mengarahkan kepada siswa-siswi SD Muhammadiyah Sintang untuk melakukan praktek cuci tangan dengan air secara bergantian. 


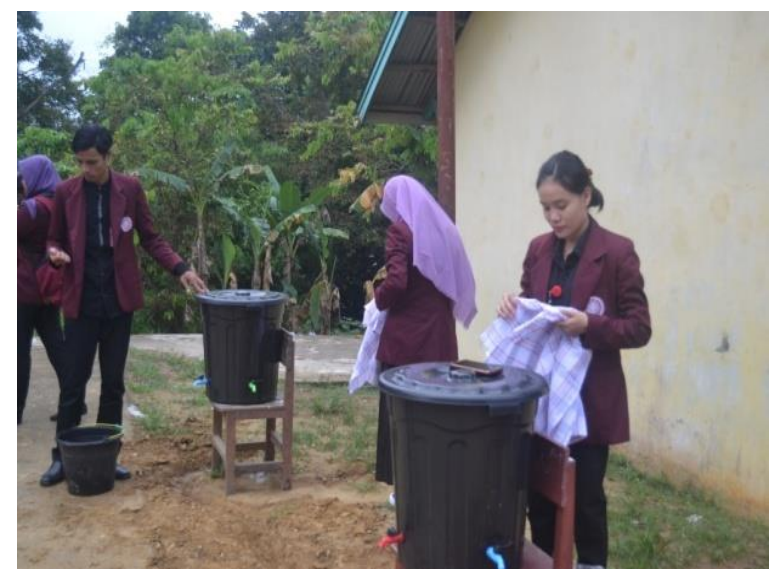

Gambar 3. Menyiapkan tempat Penampung Air bersih

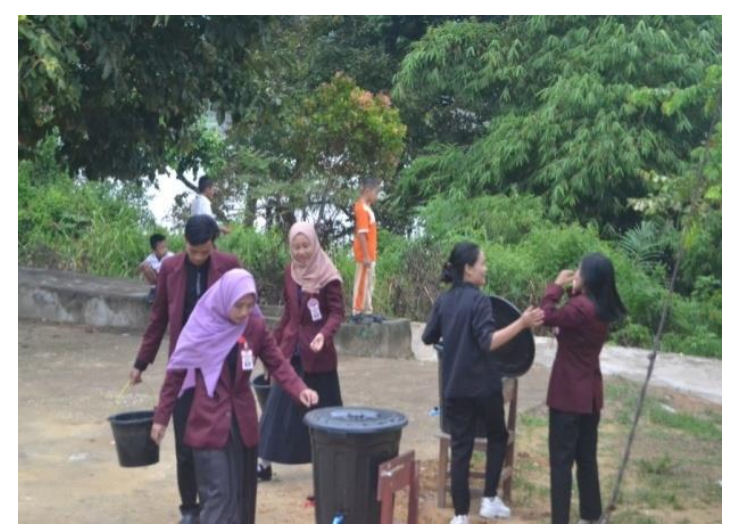

Gambar 4. Mengisi Air ke Penampungan Air

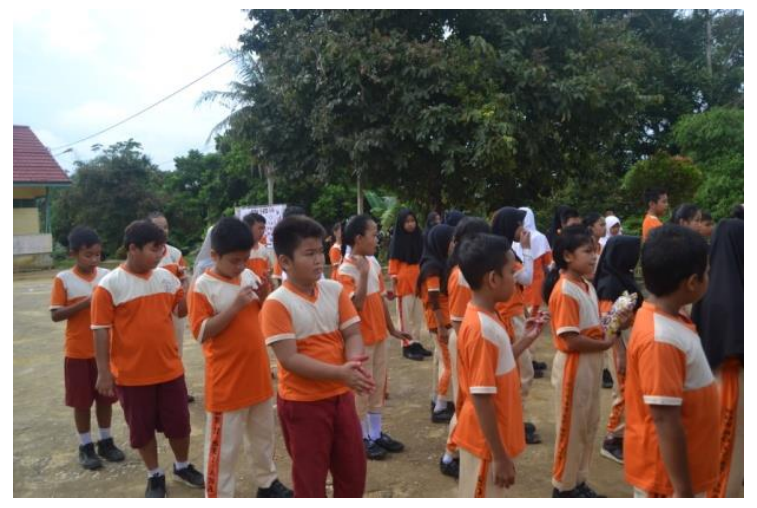

Gambar 5. Siswa-siswi mendengarkan pengarahan dilapangan

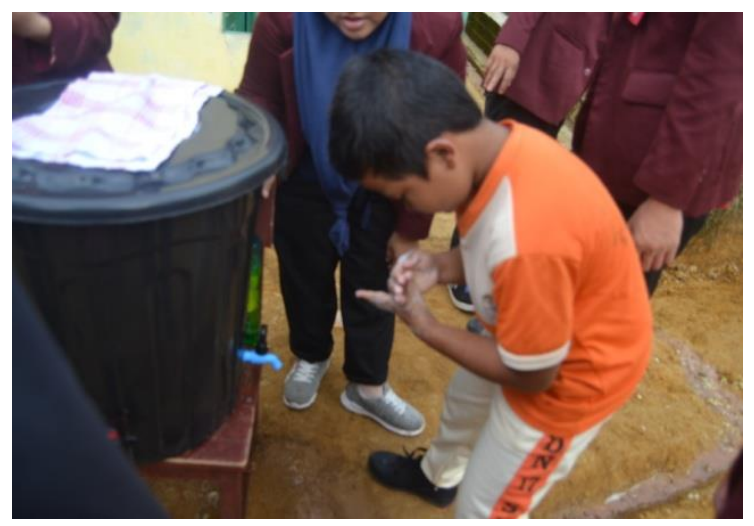


Gambar 6. Siswa-siswi mencuci tangan pakai sabun

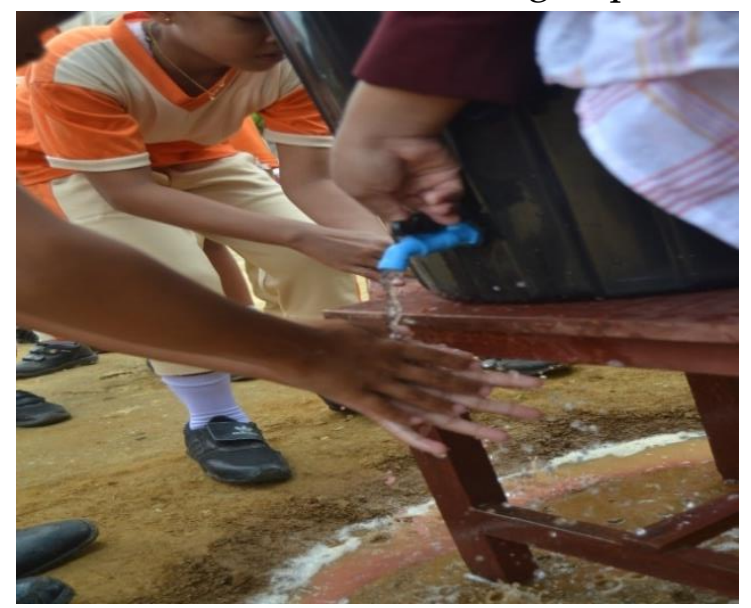

Gambar 7. Siswa-siswi mencuci tangan pakai sabun dengan air mengalir

Kegiatan pengabdian ini bertujuan untuk mencegah penyebaran COVID-19 dan meningkatkan pengetahuan serta keterampilan siswa-siswi melakukan perilaku hidup bersih dan sehat melalui cuci tangan. Dengan adanya kegiatan ini maka siswa-siswi menjadi terlatih melakukan cuci tangan dan kegiatan ini berjalan dengan efektif, tertib dan peserta sangat antusias serta siswa-siswi SD Muhammadiyah Sintang terlindungi dari penularan COVID-19.

\section{Kesimpulan}

Kegiatan pangabdian ini dapat disimpulkan, bahwa dengan terlaksananya kegiatan cuci tangan pakai sabun dengan air mengalir sebagai upaya pencegahan penyebaran COVID-19 pada Siswa-siswi SD Muhammadiyah Sintang, Kalimantan Barat. Pelaksanaan kegiatan berjalan dengan efektif, tertib dan peserta sangat antusias melakukan cuci tangan pakai sabun dengan air mengalir.

\section{Ucapan Terima Kasih}

Pada kesempatan ini, mengucapkan terima kasih kepada pihak STIKes Kapuas Raya Sintang, prodi perekam dan informasi kesehatan, pihak sekolah SD Muhammadiyah Sintang dalam hal ini Kepala Sekolah yang telah mengizinkan pelaksanaan kegiatan pengabdian.

\section{Daftar Referensi}

Burton, M., Cobb, E., G,Curtis, V Donachie, P., Judah., Schmidit, W. (2011). The eff ect of handswashing with water or soap on bacterial contamination of hands. Int. J. Environ. Res. Public Health, 8, 97-104. doi:10.3390/ijerph8010097. 
Desiyanto, F. A., \& Djannah, S. N. (2013). Efektivitas mencuci tangan menggunakan cairan pembersih tangan antiseptik (hand sanitizer) terhadap jumlah angka kuman. Jurnal Kesehatan Masyarakat (Journal of Public Health), 7(2).

Dinas Kesehatan Pemerintah Provinsi Bali. (2020). Ayo Kita Lakukan Cuci Tangan Pakai Sabun (CTPS) Sebagai Salah Satu Upaya Pencegahan Covid19. https://www.diskes.baliprov.go.id/ayo-kita-lakukan-cuci-tangan-pakai-sabunctps-sebagai-salah-satu-upaya-pencegahan-covid19/. Di Akses pada tanggal 20 Agustus 2020.

Kemenkes RI. (2020). Kesiapsiagaan menghadapi infeksi COVID-19. https://www.kemkes.go.id/folder/view/full-content/structure-faq.html. Di Akses pada tanggal 15 Oktober 2020.

Lestari, D. (2008). Metode Expository Teaching terhadap Perilaku CTPS. Universitas Katolik Soegijapranata, Semarang.

Masrul, Leon A.A, Tasnim, dkk. (2020). Pandemik COVID-19 Persoalan dan Refleksi di Indonesia. Surabaya: Yayasan Kita Menulis

Pickering, A.J, Mwanjali, M, Boehm,A.B \& Davis, J. 2010. Effi cacy of waterless hand hygiene compared with handwashing with soap : a fi eld study in Dar es Salaam. Tanzania Am. J. Trop. Med. Hyg. 82 (2). 270-278. Doi : 10. 4269/ajtmh. 2010. 09_ 0220.

S. Susilawati, R. Falefi, and A. Purwoko. (2020). "Impact of COVID-19's Pandemic on the Economy of Indonesia," Budapest Int. Res. Critics Inst. Humanit. Soc. Sci., vol. 3, no. 2, pp. 1147-1156, 2020, doi: 10.33258/birci.v3i2.954.

SATGAS COVID-19. (2020). Data sebaran covid-19. https://covid19.go.id/. Di Akses 15 Oktober 2020.

WHO. (2020). Pertanyaan dan jawaban terkait coronavirus. https://www.who.int/indonesia/news/novel-coronavirus/qa-for-public. Di Akses pada tanggal 10 Oktober 2020. 